\title{
Dynamic nature of the turnover of organic carbon, nitrogen and sulphur in the sediments of a Jamaican mangrove forest
}

\author{
D. B. Nedwell ${ }^{1}$, T. H. Blackburn ${ }^{2}$, W. J. Wiebe ${ }^{3}$ \\ ${ }^{1}$ Department of Biology, University of Essex, Colchester CO4 3SQ, United Kingdom \\ ${ }^{2}$ Department of Microbial Ecology, Institute of Biological Sciences, University of Aarhus, DK-8000 Aarhus C, Denmark \\ ${ }^{3}$ Department of Microbiology, University of Georgia, 816 Biological Sciences Building, Athens, Georgia 30602, USA
}

\begin{abstract}
Rates of oxygen uptake, sulphate reduction, carbon dioxide production, ammonium turnover, nitrogen fixation and denitrification were measured in sediments in a transect across a mangrove swamp in Jamaica. Carbon and nitrogen mineralisation increased as the transect entered the mangrove, indicating a greater availability of organic matter, probably by root excretion. Time course measurements of sulphate reduction indicated a subsurface pool of labile carbon. Carbon dioxide production within the mangrove exceeded oxygen flux across the sediment surface, indicating a subsurface source of oxygen of 28 to $179 \mathrm{mmol} \mathrm{m} \mathrm{m}^{-2} \mathrm{~d}^{-1}$ The turnover time for the sedimentary sulphide pools decreased as the transect entered the mangrove. The production of ammonium from organic nitrogen, measured by ${ }^{15} \mathrm{NH}_{4}{ }^{+}$turnover, also indicated active subsurface organic matter mineralisation. The source of this organic nitrogen is unknown. Measured rates of nitrogen fixation were too low to supply the required organic nitrogen. The estimated net availability of ammonium to the plant roots was $10 \mathrm{mmol} \mathrm{m} \mathrm{m}^{-2} \mathrm{~d}^{-1}$ This would give a productivity of $2000 \mathrm{~g} \mathrm{C} \mathrm{m}^{-2} \mathrm{yr}^{-1}$.
\end{abstract}

KEY WORDS: Mangrove sediments - Root exudates - Sulphate reduction - Organic mineralisation

\section{INTRODUCTION}

Mangroves are important tropical and subtropical communities occurring at the interface between the land and sea. They are highly productive (Odum \& Heald 1975, Dye \& Lasiak 1986, Robertson 1986), exporting organic carbon to the adjacent waters (Twilley 1985 , Boto \& Wellington 1988) where it has been suggested that they contribute to the support of coastal marine communities (Odum \& Heald 1975, Odum et al. 1982). Mangroves may also act as sinks for other elements including nitrogen and phosphorus (Nedwell 1975, Odum et al. 1982). Robertson \& Duke (1987) demonstrated the importance of mangroves as a habitat for juvenile fish and crustaceans, but it remains unclear whether mangroves represent a substantial food resource to coastal food chains. Boto \& Bunt (1981, 1982 ) estimated that as much as $46 \%$ of the primary production in an Australian mangrove forest was exported in particulate matter, although Robertson
(1986) suggested subsequently that this estimate was $20 \%$ too high because it did not consider litter consumption by crabs within the mangrove. Export from both saltmarshes and mangroves may vary considerably in relation to local geomorphology and hydrology (Nixon 1980).

However, there is little information available about the dynamics of organic degradation and nutrient recycling within mangroves. Litter bags have been used to determine the rates of degradation of detritus (e.g. Rice \& Tenore 1981), but this approach would provide little information about the pathways and rates of activity in the intact mangrove sediments. In marinedominated sediments such as mangroves, with an abundance of sulphate present, organic matter degradation is dominated by aerobic respiration and sulphate reduction (Jørgensen 1980). Kristensen et al. (1988, 1991) measured oxygen uptake by mangrove sediments in Phuket, Thailand, as an index of autotrophic and heterotrophic activity in the sediment and 
reported relatively low rates of organic degradation compared to other coastal sediments. Kristensen et al. (1991) also measured sulphate reduction rates in the same mangrove and reported that sulphate reduction could account for about all of the $\mathrm{CO}_{2}$ given off from the sediment. The present work was undertaken to investigate the rates of degradation of organic matter, both aerobically and anaerobically, which occurred within the sediments of a Jamaican mangrove forest, and to concurrently examine the dynamics of nitrogen cycling.

\section{METHODS}

Study site. The sites investigated in this work were at Oyster Bay, Falmouth Harbour (12 $\left.29^{\prime} \mathrm{N}, 77^{\circ} 38^{\prime} \mathrm{W}\right)$, on the north coast of Jamaica immediately east of the town of Falmouth. Aspects of the hydrology and biology of the Bay have been described previously (Taylor et al. 1966, Carpenter \& Seliger 1968, Seliger \& Fastie 1968, Seliger \& McElroy 1968). The Bay was surrounded by mangrove, consisting of Rhizophora mangle with Avicennia germinans at the landward side of the mangrove forest. At high tide the mangroves were generally covered with intrusive oceanic water (salinity 35 to $37 \%$, temperature 29 to $31^{\circ} \mathrm{C}$ ), although occasionally patches of low salinity river water were detected covering the mangrove at Sin 1. Five stations were selected (Fig. 1) to cover the range of mangrove-related environments within the Bay, and were representative of a transect across the man-

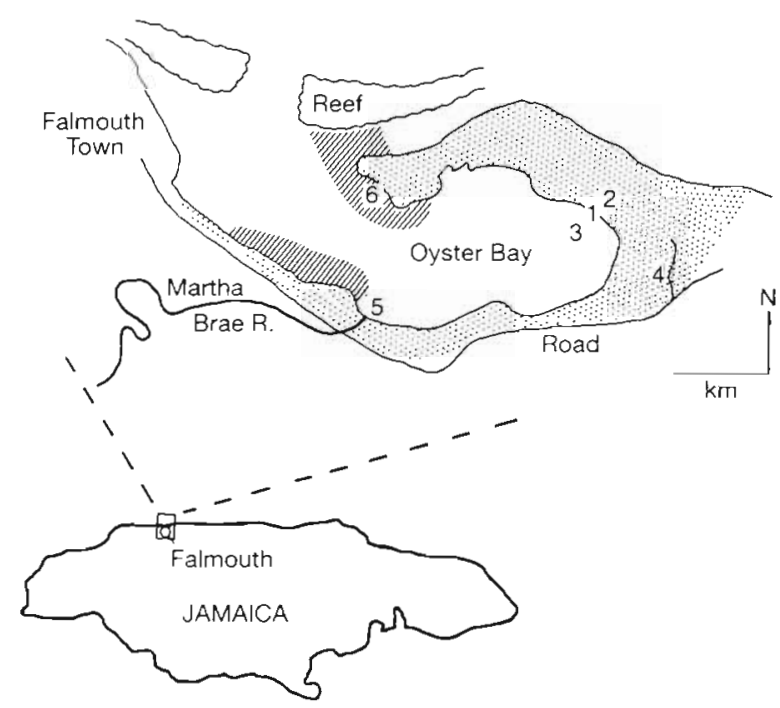

Fig. 1. Positions of sampling stations in Oyster Bay, Falmouth, Jamaica. Stippled area: mangrove $e_{i}$ hatched area: seagrass beds grove. Stn 3 was characteristic of the Bay sediment outside the mangrove influence. Stn 1 was at the edge of the mangrove and mangrove roots spread out and were present within the sediment profile at depths $>4 \mathrm{~cm}$. Sediment at Stns $3 \& 1$ had surface-oxidised layers approximately $5 \mathrm{~mm}$ deep. Stn 2 was in the centre and Stn 4 at the rear of the mangrove forest. The sediment at $\operatorname{Stn} 2$ was light in colour and appeared to be oxidised, while at Stn 4 the sediment was very black with no surface-oxidised layer. Stn 5 was typical of freshwater-dominated sediment at the periphery of the mangrove at the mouth of the Martha Brae River. Visits were made to the site in August 1990, and December 1990 to January 1991, thus covering both summer and winter periods.

Oxygen uptake by sediments. Oxygen uptake was measured by taking triplicate cores of sediment $(8 \mathrm{~cm}$ i.d. $\times$ ca $30 \mathrm{~cm}$ long) from each station in perspex core tubes. The cores were returned to the laboratory and held in a water bath at in situ field temperature (29 to $31^{\circ} \mathrm{C}$ ). Water (1 l) from the same station was present above the sediment in the core tube, and was constantly aerated with humidified air to maintain the redox gradients across the sediment-water interface. Cores were held for $6 \mathrm{~h}$ to re-equilibrate after coring and then the aeration was stopped and removal of dissolved oxygen from the supernatant water measured with a dissolved oxygen probe (model 1302, Strathkelvin Instruments, Ltd, Scotland) inserted through a cap into the water column. The probe was connected to an oxygen meter (model 781, Strathkelvin Instruments, Ltd). Care was taken to ensure the absence of air bubbles in the contained water, and the water was stirred by a magnetic stir bar beneath the cap.

The dissolved oxygen concentration during a measurement was never allowed to decrease to $<90 \%$ of air saturation. The rates of removal of dissolved oxygen were calculated by linear regression, and the slopes always conformed to straight lines $(p<0.05)$ which were significantly different $(p<0.05)$ from zero. Controls containing only seawater were always run to correct sedimentary removal of oxygen for any removal of dissolved oxygen within the water column, but the water column removal rates were always negligible.

Sulphate reduction rates. The rate of sulphate reduction in the sediment at each station was measured with triplicate small cores of sediment $(2.5 \mathrm{~cm}$ i.d. $\times$ $20 \mathrm{~cm}$ length) taken in perspex core tubes. The tubes were drilled with injection ports at $1 \mathrm{~cm}$ intervals which were sealed with silicon rubber. Each core was injected at $2 \mathrm{~cm}$ depth intervals down to $8 \mathrm{~cm}$ with ${ }^{35} \mathrm{SO}_{4}$ solution $(25 \mu \mathrm{l})$ in anaerobic seawater $[2.5 \mu \mathrm{Ci}$ (92.5 kBq); carrier-free: DuPont, Wilmington, DE, USA]. The cores were incubated for $3 \mathrm{~h}$ at in situ temperature, and then each core was extruded and sliced 
in $2 \mathrm{~cm}$ sections into $5 \mathrm{ml}$ zinc acetate solution $(5 \%$ $w / v)$ to preserve sulphides and to stop further activity. The samples were subsequently processed to recover acid-volatile sulphides (AVS) and tin-reducible sulphides (TRS, which are pyrite and sulphur) (Skyring 1985) in zinc acetate traps. Subsamples were taken from the zinc acetate traps to measure the ${ }^{35} \mathrm{~S}$ recovered in each sulphide fraction, and the remainder of the trapped sulphide was measured by thiosulphate titration (American Public Health Association 1975).

Effect of incubation time on measured sulphate reduction. Multiple cores of sediment were removed from Stn 1 and injected with ${ }^{35} \mathrm{~S}$-sulphate solution. Duplicate cores were immediately extruded, sectioned and preserved in zinc acetate solution for a $t_{0}$ control. The remaining cores were incubated at in situ temperature. Duplicate cores were removed, sectioned and fixed at intervals up to $22 \mathrm{~h}$ in order to determine whether sulphate reduction rates decreased after prolonged incubation.

Further cores of sediment from each station were taken and pore water recovered from each $2 \mathrm{~cm}$ depth slice by centrifugation. The samples were preserved by addition of $50 \mu \mathrm{l}$ zinc acetate solution to precipitate sulphides, and sulphate was measured subsequently by ion chromatography (Dionex Corp., Sunnyvale, CA, USA). The porosity of each $2 \mathrm{~cm}$ slice was also measured from the specific gravity and the water content by weight loss at $60^{\circ} \mathrm{C}$. Sulphate reduction rates were calculated according to Sorokin (1962).

Carbon dioxide production by sediments. Two sediment cores $(3.5 \mathrm{~cm}$ i.d. $\times 7 \mathrm{~cm}$ long) were incubated with ca $7 \mathrm{ml}$ of overlying water. The core was contained in a plexiglass tube $16 \mathrm{~cm}$ long, closed top and bottom with rubber stoppers. The top stopper was fitted with a magnet suspended from a nylon monofilament, rotated by an external revolving magnet (Blackburn 1987), and the closed cores were incubated in the laboratory at in situ temperature for 5 to $10 \mathrm{~h}$, depending upon the activity of the cores. The alkalinity was measured in $10 \mathrm{ml}$ replicate samples of the original water and of the overlying water after incubation (Talling 1973). The rate of change in alkalinity $\left(\sum \mathrm{CO}_{2}\right)$ $\mathrm{m}^{-2} \mathrm{~d}^{-1}$ was calculated. On occasions, the rate of $\mathrm{O}_{2}$ consumption was also measured by differences in $\mathrm{O}_{2}$, as measured by Winkler titration.

Ammonium turnover in sediments. Ammonium production and disappearance was determined by a ${ }^{15} \mathrm{NH}_{4}{ }^{+}$tracer method (Blackburn \& Henriksen 1983, Blackburn 1993). Sediment cores (20 cores in $2.5 \mathrm{~cm}$ diameter Plexiglas tubes with silicone rubber ports) were injected with ${ }^{15} \mathrm{NH}_{4}{ }^{+}\left(100 \mu l 0.01 \mathrm{M}, 99 \%{ }^{15} \mathrm{~N}\right)$ at $2 \mathrm{~cm}$ intervals. All overlying water was removed from the surface of the cores to ensure that label was not lost by diffusion upwards. A large number of cores was necessary because of the sediment heterogeneity. Half the cores were processed at $1 \mathrm{~h}$ and the rest at approximately $10 \mathrm{~h}$ after injection. Processing consisted of cutting the cores into $4 \mathrm{~cm}$ sections which were shaken with $20 \mathrm{ml}$ of $2 \mathrm{M} \mathrm{KCl}$ for $10 \mathrm{~min}$ at ambient temperature. The sediment suspension was centrifuged at $3000 \times g$ for $10 \mathrm{~min}$. The $\mathrm{NH}_{4}{ }^{+}$and ${ }^{15} \mathrm{NH}_{4}{ }^{+}$concentrations were determined by colorimetric analysis (Solórzano 1969) and by mass spectrometry (Blackburn 1993) respectively. The gross rate of $\mathrm{NH}_{4}{ }^{+}$production was calculated from the dilution of the ${ }^{15} \mathrm{NH}_{4}{ }^{+}$label between the 2 time points. The initial $1 \mathrm{~h}$ incubation was to allow the ${ }^{15} \mathrm{NH}_{4}{ }^{+}$to interact with the sediment; normally losses occur due to physical process.

Denitrification and nitrogen fixation rates. The simultaneous measurement of denitrification and nitrogen fixation has been done in soil (Yoshinari et al. 1977). The procedure for measuring denitrification in sediments was essentially that of Anderson et al. (1984). The sediment (ca $7 \mathrm{~cm}$ long $\times 3.5 \mathrm{~cm}$ i.d. Plexiglas tubes with silicone rubber ports) was gently overlaid with water (ca $7 \mathrm{~cm}$ ). The tubes were closed with rubber stoppers, the top stopper being fitted with a magnetic stirrer as for the carbon dioxide flux measurements. Six sediment cores, with no gas headspace, were injected with $100 \mu$ l of acetylene-saturated seawater at $0.5 \mathrm{~cm}$ intervals, and the overlying water was adjusted to $10 \%$ saturation with acetylene. Surplus water was allowed to escape through a needle. Half the cores were processed after ca $1 \mathrm{~h}$ and the rest after ca $3 \mathrm{~h}$. Processing consisted of removing $25 \mathrm{ml}$ of the overlying water to an evacuated $38 \mathrm{ml}$ serum bottle which was shaken vigorously. The remainder of the overlying water was discarded and the sediment transferred to a $250 \mathrm{ml}$ bottle containing $50 \mathrm{ml}$ seawater. The sediment was shaken vigorously to create a suspension (10 min). Samples $(3 \mathrm{ml}$ ) of the headspace from the water and from the sediment suspensions were taken with a syringe and stored in evacuated $3 \mathrm{ml}$ tubes (Venoject) until analysed for $\mathrm{N}_{2} \mathrm{O}$ and ethylene. The total production of $\mathrm{N}_{2} \mathrm{O}$ and ethylene was calculated, using appropriate Bunsen coefficients.

Carbon dioxide profiles in sediments. The alkalinity in $1 \mathrm{ml}$ samples of pore water was titrated (Talling 1973) after the addition of $10 \mathrm{ml}$ of distilled water. Alkalinity values are equated with $\mathrm{CO}_{2}$ concentrations.

\section{RESULTS}

The stations, as described above in the sequence 3 , $1,2,4,5$, represented a transect across the mangrove and our results are therefore illustrated in the same order. There were no significant differences between 


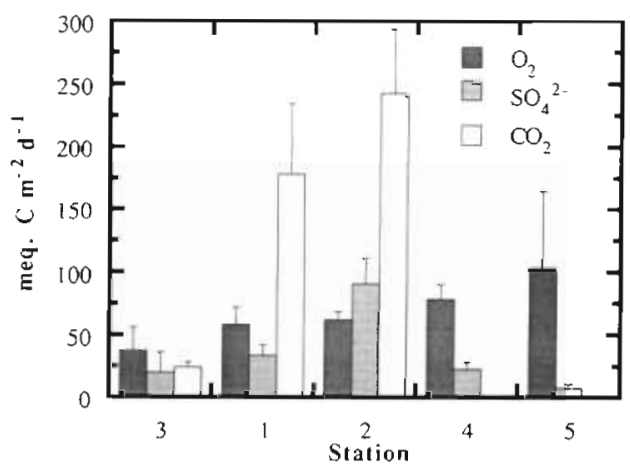

Fig. 2. Rates of carbon mineralisation in a transect of 5 stations across a mangrove swamp. Error bar is $+1 \mathrm{SE}_{i} \mathrm{n}=5$

measured rates and concentrations on the 2 visits, and all measurements were therefore pooled. Errors indicated in the results therefore include any differences due to seasonal variations.

Fig. 2 shows the daily rates of oxygen uptake by the sediment and the depth-integrated values for sulphate reduction, both in terms of milliequivalents (meq.) of organic carbon oxidised by each process, calculated stoichiometrically. For Stns 1 to 3 measurements of $\mathrm{CO}_{2}$ output were also made and these are shown also in Fig. 2. Our rates of $\mathrm{O}_{2}$ uptake (31 to $103 \mathrm{mmol} \mathrm{m}^{-2}$ $\mathrm{d}^{-1}$ ) measured in the mangrove were similar to, but generally greater than, those reported (Kristensen et al. 1988, 1991) for the Ao Nam Bor mangrove swamp in Phuket, Thailand (17 to $61 \mathrm{mmol} \mathrm{O} \mathrm{m}^{-2} \mathrm{~d}^{-1}$ ). These oxygen uptake rates are, however, in the lower part of the range reported for coastal and intertidal sediments in more temperate regions (Mackin \& Swider 1989). Similarly, our rates of sulphate reduction (3.9 to $45.2 \mathrm{mmol} \mathrm{SO}_{4} \mathrm{~m}^{-2} \mathrm{~d}^{-1}$ ) were similar to those reported

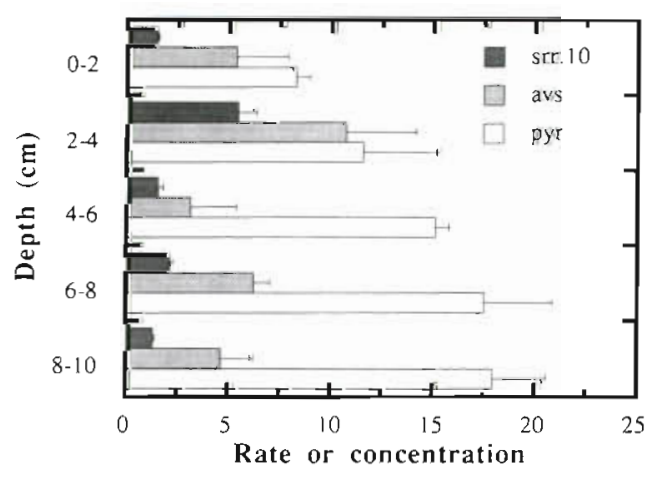

Fig. 3. Vertical profiles of sulphate reduction rates (srr) ( $\mu$ mol $S \mathrm{ml}^{-1} \mathrm{~d}^{-1}$; values shown are $10 \times$ the measured values to place them on the same scale); acid-volatile sulphide (AVS) and pyrite + sulphur (pyr) ( $\mathrm{mmol} \mathrm{S} \mathrm{ml}^{-1}$ ) in sediment at Strn 1 at the edge of the mangrove swamp. Error bar is $+1 \mathrm{SE}_{;} \mathrm{n}=3$

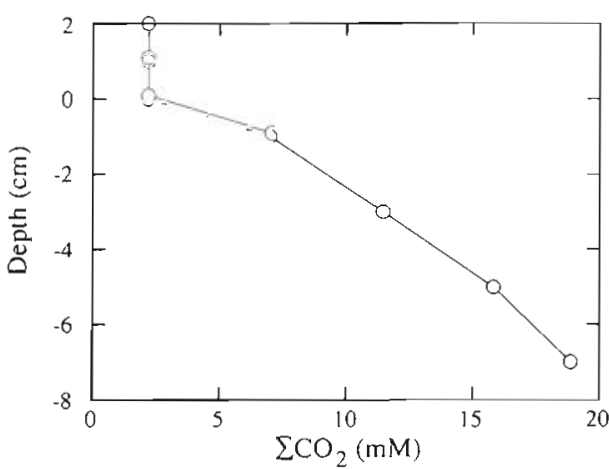

Fig. 4. Vertical profile of alkalinity at Stn 1

for the Ao Nam Bor mangrove in Thailand (27.8 to $49.7 \mathrm{mmol} \mathrm{SO}_{4} \mathrm{~m}^{-2} \mathrm{~d}^{-1}$; Kristensen et al. 1991) and for a Bermudan mangrove (14 to $28 \mathrm{mmol} \mathrm{SO}_{4} \mathrm{~m}^{-2} \mathrm{~d}^{-1}$; Hines \& Lyons 1982).

Depth profiles of the concentrations of acid-volatile sulphide and tin-reducible sulphide (pyrite + sulphur) are shown (Fig. 3) for Stn 1, together with the measured rates of sulphate reduction at each depth. (The sulphate reduction rates are scaled to illustrate them clearly on the same axes, and the measured rate has been multiplied by 10. )

The alkalinity concentrations in the pore water of the sediment at Stn 1 (Fig. 4) indicated an almost linear gradient. There are, however, deviations from this linearity indicating $\mathrm{CO}_{2}$ production in the 0 to $6 \mathrm{~cm}$ stratum. The gradient from $1 \mathrm{~cm}$ to the surface would have given a flux of ca $90 \mathrm{mmol} \mathrm{CO} \mathrm{Cm}^{-2} \mathrm{~d}^{-1}$. This is, if anything, an underestimation, as the gradient would have been considerably greater had the concentration been measured closer to the sediment surface.

Fig. 5 shows the total amounts of sulphate reduction which had occurred in $8 \mathrm{~cm}$ cores of sediment from Stn 1, plotted in relation to the time of incubation after the cores were removed. Clearly, sulphate reduction was linear over the first 7 to $8 \mathrm{~h}$, but after this time

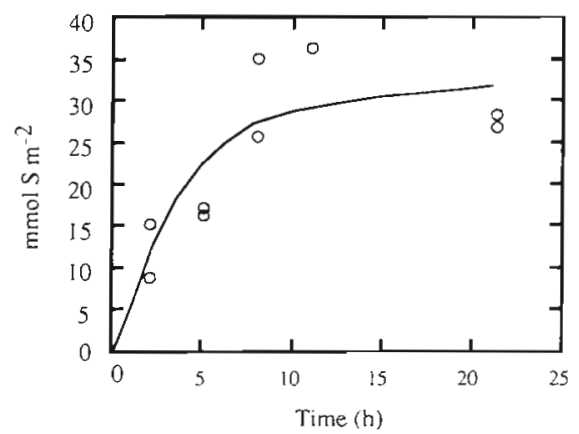

Fig. 5. Time course of sulphate reduction in sediment $\{0$ to $8 \mathrm{~cm}$ ) from $\operatorname{Stn} 1$ 
Table 1. Ammonium production rates in sediment (errors indicated are $\pm \mathrm{SE}, \mathrm{n}=10$ )

\begin{tabular}{|c|c|c|c|c|c|c|}
\hline \multirow{2}{*}{$\begin{array}{r}\text { Incubation times } t_{1}, t_{2}(\mathrm{~d}): \\
\text { Depth }(\mathrm{cm}):\end{array}$} & \multicolumn{2}{|c|}{$\begin{array}{c}\operatorname{Stn} 1 \\
0.21,1.04\end{array}$} & \multicolumn{2}{|c|}{$\begin{array}{c}\text { Stn } 2 \\
0.05,0.53\end{array}$} & \multicolumn{2}{|c|}{$\begin{array}{c}\operatorname{Stn} 4 \\
0.13,0.42\end{array}$} \\
\hline & $0-4$ & $4-8$ & $0-4$ & $4-8$ & $0-4$ & $4-8$ \\
\hline \multicolumn{7}{|l|}{$\mathrm{NH}_{4}{ }^{+}$conc. $(\mathrm{nmol} \mathrm{cm}-3$ ) at: } \\
\hline$t_{0}$ & 272 & 530 & 32 & 3.3 & 70 & 111 \\
\hline$t_{1}$ & $482 \pm 229$ & $744 \pm 265$ & $135 \pm 47$ & $59 \pm 28$ & $107 \pm 46$ & $213 \pm 99$ \\
\hline$t_{2}$ & $476 \pm 148$ & $748 \pm 175$ & $49 \pm 48$ & $15 \pm 12$ & $116 \pm 78$ & $327 \pm 51$ \\
\hline \multicolumn{7}{|l|}{$\%{ }^{15} \mathrm{~N}$ at: } \\
\hline$t_{1}$ & $13.13 \pm 3.9$ & $9.33 \pm 2.47$ & $18.80 \pm 5.52$ & $23.42 \pm 6.35$ & $27.80 \pm 9.42$ & $32.03 \pm 17.46$ \\
\hline$t_{2}$ & $9.09 \pm 2.67$ & $6.65 \pm 1.95$ & $8.96 \pm 2.05$ & $18.79 \pm 8.77$ & $32.01 \pm 6.55$ & $17.68 \pm 2.54$ \\
\hline \multicolumn{7}{|l|}{$\%$ recovery of ${ }^{15} \mathrm{NH}_{4}{ }^{+}$at: } \\
\hline$t_{1}$ & $28.08 \pm 9.76$ & $31.25 \pm 4.89$ & $12.44 \pm 4.05$ & $7.81 \pm 3.60$ & $14.18 \pm 2.75$ & $26.80 \pm 3.70$ \\
\hline$t_{2}$ & $19.79 \pm 2.17$ & $22.90 \pm 4.08$ & $2.26 \pm 1.48$ & $1.33 \pm 0.56$ & $17.03 \pm 7.80$ & $28.72 \pm 4.86$ \\
\hline$k\left(\mathrm{~d}^{-1}\right)$ & 0.46 & 0.43 & 1.59 & 0.47 & - & 2.02 \\
\hline $\begin{array}{l}\mathrm{NH}_{4}^{+} \text {production } \\
\left(\mathrm{mmol} \mathrm{m} \mathrm{m}^{-2} \mathrm{~d}^{-1}\right)\end{array}$ & 8.75 & 12.71 & 5.84 & 0.70 & - & 21.81 \\
\hline $\begin{array}{l}\sum \mathrm{NH}_{4}^{+} \text {production } \\
\left(\mathrm{mmol} \mathrm{m}^{-2} \mathrm{~d}^{-1}\right)\end{array}$ & \multicolumn{2}{|c|}{21.46} & \multicolumn{2}{|c|}{6.54} & \multicolumn{2}{|c|}{21.81} \\
\hline
\end{tabular}

sulphate reduction ceased. This was not the result of sulphate limitation, sulphate remaining at $>18 \mathrm{mM}$ in the pore water.

The results of the ${ }^{15} \mathrm{NH}_{4}{ }^{+}$tracer addition to the sediments at Stns $1,2 \& 4$ are seen in Table 1. The initial $\mathrm{NH}_{4}{ }^{+}$concentration $\left(t_{0}\right)$ was quite high at Stn 1 , very low at $\operatorname{Stn} 2$ and a little higher at $\operatorname{Stn} 4$. At time $t_{0}$, $200 \mu \mathrm{l}$ of ${ }^{15} \mathrm{NH}_{4}{ }^{+}$was added per $\mathrm{cm}^{3}$ sediment and the concentration remained high at $t_{1}$ and $t_{2}(0.21$ and 1.04 d) in Stn 1 sediment, even though the \% recovery of ${ }^{15} \mathrm{~N}$ was low at both depths and at both times. This indicated a fast tumover of $\mathrm{NH}_{4}{ }^{+}$and the most appropriate treatment of the data was to calculate the first order rate constants (Blackburn 1993). Decrease in \% ${ }^{15} \mathrm{NH}_{4}{ }^{+}$can only occur by production of ${ }^{14} \mathrm{NH}_{4}{ }^{+}$, and it is this rate which we measured. Uptake of $\mathrm{NH}_{4}{ }^{+}$, if it results in a change in pool size, will alter the calculations, but cannot itself change the concentration of added ${ }^{15} \mathrm{NH}_{4}{ }^{+}$. The turnovers of 0.46 and $0.43 \mathrm{~d}^{-1}$ at 0 to $4 \mathrm{~cm}$ and 4 to $8 \mathrm{~cm}$, respectively, gave a summed rate of gross $\mathrm{NH}_{4}^{+}$production of $21.46 \mathrm{mmol} \mathrm{m} \mathrm{m}^{-2} \mathrm{~d}^{-1}$.

At Stn 2, $200 \mu \mathrm{l}$ of ${ }^{15} \mathrm{NH}_{4}{ }^{+}$was also added per $\mathrm{cm}^{3}$ sediment at $t_{0}$, but already after $0.05 \mathrm{~d}\left(t_{1}\right)$ the initial concentrations after this addition of 232 and $233 \mathrm{nmol}$ $\mathrm{cm}^{-3}$ at the 2 depths had fallen to 135 and $59 \mathrm{nmol}$ $\mathrm{cm}^{-3}$, and further to 49 and $15 \mathrm{nmol} \mathrm{cm} \mathrm{cm}^{-3}$ after $0.53 \mathrm{~d}$ $\left(t_{2}\right)$. The \% ${ }^{15} \mathrm{~N}$ and $\%$ recovery of ${ }^{15} \mathrm{NH}_{4}{ }^{+}$indicated a very rapid uptake and production of $\mathrm{NH}_{4}{ }^{+}$. The changing pool size during the incubation should be included in the calculation of turnover rate (Blackburn 1979), but the rate of $\mathrm{NH}_{4}{ }^{+}$uptake was probably changing during the incubation in an unknown manner. The first order rate constants $(k)$ indicated that 1.59 and $0.47 \mathrm{~d}^{-1}$ of the pool was turning over at the 2 depths, respectively. The rates of production, however, were relatively low, 5.84 and $0.70 \mathrm{mmol} \mathrm{m} \mathrm{m}^{-2} \mathrm{~d}^{-1}$. From a different calculation based on the calculated amount of ${ }^{15} \mathrm{NH}_{4}{ }^{+}$that should have been present at $t_{0}$, the $k$ values for the first $0.05 \mathrm{~d}$ would have been 3.18 and $1.59 \mathrm{~d}^{-1}$, giving rates of 23 and $16 \mathrm{mmol} \mathrm{m}^{-2}$ for the strata 0 to 4 and 4 to $8 \mathrm{~cm}$, respectively. Due to nonbiological ammonium losses these rates are probably too high, but the summed rates lie between the

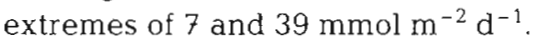

At Stn 4, there was little activity in the 0 to $4 \mathrm{~cm}$ stratum. There was no change in $\mathrm{NH}_{4}{ }^{+}$concentration between 0.13 and $0.42 \mathrm{~d}$ after incubation, there was a low \% recovery of ${ }^{15} \mathrm{NH}_{4}{ }^{+}$which increased with incubation, typical of a very silty sediment. The 4 to $8 \mathrm{~cm}$ stratum showed some disappearance of the added ${ }^{15} \mathrm{NH}_{4}{ }^{+}$after $0.13 \mathrm{~d}$, followed by $\mathrm{NH}_{4}{ }^{+}$production without any ${ }^{15} \mathrm{NH}_{4}{ }^{+}$dilution. This indicated that the roots may have been inactive after continued incubation. The gross rate of $\mathrm{NH}_{4}{ }^{+}$production was $21.81 \mathrm{mmol} \mathrm{m}^{-2}$ $\mathrm{d}^{-1}$. The data for the rates of denitrification and nitrogen fixation are presented in Fig. 6. The stations are shown in the same order as in Fig. 2, with Stn 2 being in the centre of the mangroves. The data indicate that Stn 2 was the most active in denitrification and nitrogen fixation, both rates were ca $2 \mathrm{mmol} \mathrm{m}^{-2} \mathrm{~d}^{-1}$. 


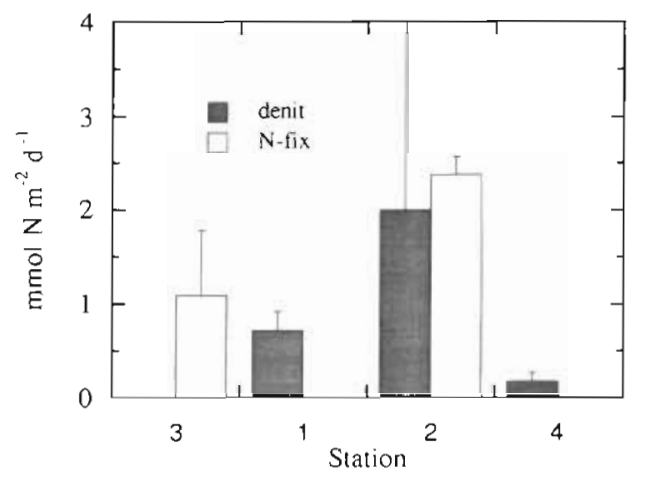

Fig. 6. Denitrification and nitrogen fixation rates in a transect of 4 stations across the mangrove swamp. Error bar is $+1 \mathrm{SE}_{i}$ $n=3$

\section{DISCUSSION}

The data in Fig. 2 show a trend of increasing sedimentary biological activity from the Bay sediment into the sediment of the mangrove forest. Oxygen uptake rates increased from the Bay site through to the freshwater-dominated $\mathrm{Stn} 5$. The production of $\mathrm{CO}_{2}$ also increased dramatically from Stn 3, through Stn 1 and into the mangrove itself at Stn 2. (We had no measurements of $\mathrm{CO}_{2}$ output for Stns 4 \& 5.) In contrast, sulphate reduction rates increased going into the mangrove to Stn 2, but were lower in Stns 4 \& 5 (Fig. 2). Kristensen et al. (1991) also reported sulphate reduction rates higher inside a mangrove than on its periphery. These data strongly suggest that the availability of organic carbon for mineralisation in the sediment increased as the transect entered the mangrove forest.

At $\operatorname{Stn} 4$, at the back of the mangrove forest, the sediment was only inundated for short periods at high tide, and this was insufficient to replenish the sedimentary sulphate pool, which was low (typically $<2 \mathrm{mM}$ in the pore water). Turnover of sulphate at this site was high but the sulphate reduction rate was limited by the small sulphate pool, and aerobic metabolism predominated. Stn 4 had high concentrations of both AVS (10 to $12 \mu \mathrm{mol} \mathrm{S} \mathrm{ml}{ }^{-1}$ ) and of TRS ( $>20 \mu \mathrm{mol}$ $\mathrm{S} \mathrm{ml}{ }^{-1}$ ) in the top 0 to $5 \mathrm{~cm}$ of sediment. In contrast, at Stn 5 the sulphate reduction rate in this freshwaterdominated sediment was also sulphate limited $(<9 \mathrm{mM}$ in pore waters) but ${ }^{35} \mathrm{~S}$-sulphate turnover, in contrast to $\operatorname{Stn} 4$, was low. There was negligible AVS, but some TRS $\left(<20 \mu \mathrm{mol} \mathrm{S} \mathrm{ml}{ }^{-1}\right)$ was present at this station.

The proportions of organic matter which were apparently oxidised by sulphate reduction can be calculated if it is assumed that organic matter oxidised by sulphate reduction was included in the sedimentary uptake of oxygen because of aerobic reoxidation of sulphide at the sediment surface (Andersen \& Hargrave 1984, Kristensen \& Blackburn 1987). The propor- tions of the organic carbon mineralisation which could be attributed to sulphate reduction compared to aerobic respiration within the sediment at each site varied between 7.6 to $147 \%$. The smallest proportions were at Stns 4 \& 5, where sulphate reduction was sulphatelimited. Significant contribution of $\mathrm{Fe}^{3+}, \mathrm{Mn}^{4+}$ or $\mathrm{NO}_{3}{ }^{-}$ to organic matter degradation at Stns 1 to 3 can be discounted as the seawater which covered them had extremely low concentrations, $<1 \mu \mathrm{M}$. It is possible that at the low sulphate Stns $4 \& 5$ methane output from the sediments could have occurred, and Fe and $\mathrm{Mn}$ respiration may have been significant at the oligohaline Stn 5 (see Lovley 1991), but we have no measurements of these. If significant, it would have resulted in our underestimating carbon mineralisation at the low sulphate sites, but this would not effect the measured balance between $\mathrm{O}_{2}$ uptake and sulphate reduction. At the high sulphate stations methanogenesis may be expected to be inhibited by sulphate reduction (Abram \& Nedwell 1978). About half the organic matter was mineralised by sulphate reduction at Stn 3 in the lagoon, a proportion similar to those reported elsewhere in other marine sediments (Jørgensen 1980). However, at Stn 1, and at Stn 2 in the middle of the mangrove, the proportion of organic carbon mineralised by sulphate reduction exceeded that attributable to oxygen uptake at the surface of the sediment $(147 \%$ at Stn 2$)$. This implied possible subsurface sources of organic electron donors for the sulphatereducing bacteria in the sediment. The profile of alkalinity (Fig. 4) also indicated subsurface oxidation of organic carbon to $\mathrm{CO}_{2}$. Comparison of the $\mathrm{CO}_{2}$ produced by $\mathrm{O}_{2}$ uptake with the measured $\mathrm{CO}_{2}$ production rates at Stns 1 to 3 (Table 2) showed that at $\operatorname{Stn} 3$. outside the mangrove, $\mathrm{O}_{2}$ uptake and $\mathrm{CO}_{2}$ production were almost equal, but at Stns $1 \& 2$ there was an excess of $\mathrm{CO}_{2}$ production over and above what was stoichiometrically attributable to aerobic mineralisation. Boto et al. (1989) have previously described subsurface peaks of dissolved organic carbon in high-and mid-intertidal Australian mangrove sediments, DOC concentration peaks coinciding with the depth of Rhizophora sp. roots. It therefore seems possible that or-

Table 2. Organic carbon mineralisation in sediments (in meq. C $m^{-2} \mathrm{~d}^{-1}$ )

\begin{tabular}{|ccccc|}
\hline Stn & $\begin{array}{c}\mathrm{O}_{2} \\
\text { uptake }\end{array}$ & $\begin{array}{c}\mathrm{SO}_{4}{ }^{2-} \\
\text { reduction }\end{array}$ & $\begin{array}{c}\mathrm{CO}_{2} \\
\text { production }\end{array}$ & $\begin{array}{c}\mathrm{CO}_{2} \text { production } \\
-\mathrm{O}_{2} \text { uptake }\end{array}$ \\
\hline 3 & 38 & 20 & 24 & -14 \\
1 & 58 & 34 & 178 & 121 \\
2 & 62 & 90 & 241 & 179 \\
4 & 78 & 23 & - & - \\
5 & 103 & 8 & - & - \\
\hline
\end{tabular}


ganic matter was passed out from the mangrove roots into the sediment, where it was available to microbial degradation. Similar subsurface exudation of organic matter has been reported by the roots of Spartina sp. (Howarth \& Teal 1979, Skyring et al. 1979).

The possibility of a subsurface pool of labile organic material is reinforced by the results of the measurements of sulphate reduction rates (Fig. 5) at Stn 1 where mangrove roots were present. The sulphate reduction continued for only 7 to $8 \mathrm{~h}$ before ceasing, presumably because available organic material in the sediment, previously exuded from the roots, became exhausted. (Further exudation would have ceased after removal of the cores.) The sulphate reduction plateaued at about $3.0 \mu \mathrm{mol} \mathrm{SO}_{4} \mathrm{~cm}^{-2}$, and this indicated a pool size of available organic matter initially present in the sediment of $6.0 \mu \mathrm{mol}$ org. $\mathrm{C} \mathrm{cm}^{-2}$ over the 0 to $8 \mathrm{~cm}$ horizon. As this depletion occurred in about $8 \mathrm{~h}$, over $24 \mathrm{~h}$ the total sulphate reduction would be equivalent to $90 \mathrm{mmol} \mathrm{SO}_{4} \mathrm{~m}^{-2} \mathrm{~d}^{-1}$, equivalent to $180 \mathrm{mmol} \mathrm{C} \mathrm{m}{ }^{-2} \mathrm{~d}^{-1}$ used. Roden \& Tuttle (1993) have recently hypothesised that plateauing of ${ }^{35} \mathrm{~S}^{2-}$ recovery after 2 to $3 \mathrm{~h}$ incubation in oligohaline, low sulphate sediment was due to sulphide reoxidation; but, this explanation for our data is unlikely in the high sulphate and high sulphide, euryhaline sediments of the mangrove edge

Subsurface oxidation of organic matter must be driven by an oxidation capacity which cannot be accounted for by the measured rate of sulphate reduction. Examination of the profiles of sulphides compared to the rates of sulphate reduction (Fig. 3) suggests the possibility of rapid subsurface reoxidation of the sulphide produced from sulphate reduction. At Stn 3, outside the mangrove forest, the total sulphide in AVS + TRS was $1.24 \mathrm{~mol} \mathrm{~S} \mathrm{~m} \mathrm{~m}^{-2}$ over the 0 to $8 \mathrm{~cm}$ horizon and average sulphate reduction was $10 \mathrm{mmol} \mathrm{S} \mathrm{m} \mathrm{S} \mathrm{d}^{-1}$. which was equivalent to an average turnover time of sulphides of 124 d. At Stn 1 on the edge of the mangrove forest the total sulphide in both AVS and TRS was equivalent to $1.5 \mathrm{~mol} \mathrm{~S} \mathrm{~m} \mathrm{~m}^{-2}$ while sulphate reduction accounted for $16.9 \mathrm{mmol} \mathrm{S} \mathrm{cm} \mathrm{cm}^{-2} \mathrm{~d}^{-1}$; or a sulphide turnover time of $88.8 \mathrm{~d}$. At Stn 2 in the centre of the mangrove the total sulphide in AVS + TRS was 1.09 mol S m$~^{-2}$ and sulphate reduction rate was $45.2 \mathrm{mmol}$ $\mathrm{S} \mathrm{m}^{-2} \mathrm{~d}^{-1}$, equivalent to a turnover time of only $24.3 \mathrm{~d}$. There was a trend, therefore, of faster turnover of sulphide going from the Bay into the mangrove, emphasising the dynamic nature of the sulphide pools. If it was assumed that only AVS was turning over, and that pyrite (TRS) was inert, then the turnover times would be about twice as fast. Blackburn et al. (1987) reported turnover for AVS only of $38 \mathrm{~d}$ in sediment among Avicennia sp. roots in a Thai mangrove, which is similar to our value.
When it is considered that total $\mathrm{O}_{2}$ supply must also account for sulphide reoxidation, our results can only be reconciled if there was also a subsurface source of oxidising capacity. Scholander et al. (1955) showed that Avicennia germinans was able to transport air to roots growing in anerobic sediment through its aerenchyma, and Nickerson \& Thibodeau (1985) demonstrated that sedimentary sulphide concentrations were significantly smaller around the pneumatophores of $A$. germinans than in areas of non-vegetated sediment. Anderson \& Kristensen (1988) have reported the presence of an oxic layer around the roots of $A$. marina, while Kristensen et al. (1988) have also described in the porewater of an Asian mangrove forest a subsurface peak of nitrate associated with the roots of $\mathrm{Rhi}$ zophora apiculata, which might also be attributed to $\mathrm{O}_{2}$ evolution from the roots. The transport of $\mathrm{O}_{2}$ to the rhizosphere of the mangroves could explain the apparent imbalance between surface $\mathrm{O}_{2}$ uptake and sulphate reduction. Some of the subsurface oxidation of organic matter may be by aerobic oxidation in the rhizosphere of the mangrove roots, but also some of the sulphide produced by sulphate reduction may be subjected to subsurface reoxidation by oxygen within the sediment (Carlson \& Yarboro 1988). In the latter case sulphate would be acting essentially as an oxygen carrier, sulphide being reoxidised by $\mathrm{O}_{2}$ diffusing from the roots, a possibility emphasised by the short turnover times of the sulphide pools in the mangrove sediments. The output of $\mathrm{O}_{2}$ from the roots can be estimated from the difference between surface $\mathrm{O}_{2}$ uptake and $\mathrm{CO}_{2}$ production at Stn 2 as equivalent to $179 \mathrm{mmol} \mathrm{O}_{2} \mathrm{~m}^{-2} \mathrm{~d}^{-1}$. Alternatively, assuming complete reoxidation of sulphide at the surface, the difference between $\mathrm{O}_{2}$ flux and sulphate reduction (Table 2) would give a deficit of $28 \mathrm{mmol} \mathrm{m} \mathrm{m}^{-2} \mathrm{~d}^{-1}$. Kristensen et al. (1991) also reported imbalance between $\mathrm{CO}_{2}$ production and sulphate reduction within the Ao Nam Bor mangrove and hypothesised vertical translocation of organic substrates within the sediment, either by bioturbation or by subsurface root growth, combined with subsurface oxidation of sulphide in the burrow walls of sedimentary infauna.

The measurements of ammonium turnover in the mangrove sediments also reinforced the concept of dynamic turnover of different pools within the mangrove sediments. The gross rates of ammonium production at Stns 1, $2 \& 4$ were 21, 7 to 39 and $22 \mathrm{mmol}$ $\mathrm{NH}_{4}{ }^{+} \mathrm{m}^{-2} \mathrm{~d}^{-1}$ respectively. By comparison, in the Ao Yon mangrove in Thailand an ammonium production rate of $18 \mathrm{mmol} \mathrm{m} \mathrm{m}^{-2} \mathrm{~d}^{-1}$ was measured in Avicennia sp. rhizosphere (Blackburn et al. 1987). We have taken $\mathrm{NH}_{4}{ }^{+}$production to be of the order of $20 \mathrm{mmol} \mathrm{m}^{-2} \mathrm{~d}^{-1}$ of which 10 may have gone to bacterial biomass (Blackburn 1987). This would give an estimate of root 
uptake of $10 \mathrm{mmol} \mathrm{NH}_{4}{ }^{+} \mathrm{m}^{-2} \mathrm{~d}^{-1}$. It is attractive to think that the source of the organic nitrogen which gives rise to the high rates of ammonium production. might be biomass derived from nitrogen fixation driven by root secretion of soluble carbon. It is known that nitrogen fixation is active in the rhizosphere of mangroves (Zuberer \& Silver 1978, Holguin et al. 1992). Our values for nitrogen fixation are only $2 \mathrm{mmol} \mathrm{N} \mathrm{m}{ }^{-2}$ $\mathrm{d}^{-1}$ and are counterbalanced by denitrification rates of the same order (Fig. 6). It is likely that nitrogen fixation is tightly coupled to a whole and completely functional root system, delivering dissolved organic carbon and oxygen. Our measurements of nitrogen fixation were made with sediment cores containing excised roots and therefore may underestimate in situ rates. It remains to be seen whether nitrogen fixation actually produces net fixed nitrogen in mangrove forests.

The nitrogen uptake by mangrove roots was estimated as $10 \mathrm{mmol} \mathrm{N} \mathrm{m}^{-2} \mathrm{~d}^{-1}$. At a $\mathrm{C}: \mathrm{N}$ ratio of $40: 1$ in mangrove biomass, this $\mathrm{N}$ uptake would be equivalent to a production rate of ca $2000 \mathrm{~g} \mathrm{C} \mathrm{m}^{-2} \mathrm{yr}^{-1}$. By comparison, estimates of net primary production in Thai mangroves range between 500 and $2000 \mathrm{~g} \mathrm{C} \mathrm{m}^{-2} \mathrm{yr}^{-1}$ (Blackburn et al. 1987, Kristensen et al. 1988) which is of similar magnitude to our estimate for the Jamaican mangrove.

Acknowledgements. This work was supported by a grant to W.J.W. by USAID Program in Science and Technology Cooperation (PSTC): Diversity of Biological Resources; Atmospheric, Marine and Earth Sciences; and a NERC Small Research Grant (GR9/246A) to D.B.N. We thank Dr Jeremy Woodley, Director of the Discovery Bay Marine Laboratory of the University of the West Indies, and the staff for their assistance.

\section{LITERATURE CITED}

Abram, J. W., Nedwell, D. B. (1978). Inhibition of methanogenesis by sulphate reducing bacteria competing for transferred hydrogen. Arch. Microbiol. 117: 89-92

American Public Health Association (1975). Standard methods for the examination of water and waste water, 14th edn. APHA, Washington, DC, p. 1193

Andersen, F. Ø., Hargrave, B. T (1984). Effects of Spartina detritus enrichment on aerobic/anaerobic benthic metabolism in an intertidal sediment. Mar. Ecol. Prog. Ser. 16: $161-171$

Andersen, F. $\varnothing$., Kristensen, E. (1988). Oxygen microgradients in the rhizosphere of the mangrove Avicennia marina. Mar. Ecol. Prog. Ser. 44: 201-204

Andersen, T. K., Jensen, M. H., Sørensen, J. (1984). Diurnal variation of nitrogen cycling in coastal marine sediments. I. Denitrification. Mar. Biol. 83: 171-176

Blackburn, T. H. (1987). Nitrogen cycle in marine sediments. Ophelia 26: $65-76$

Blackburn, T H. (1979). Method for measuring rates of $\mathrm{NH}_{4}{ }^{+}$ turnover in anoxic marine sediments using a ${ }^{15} \mathrm{~N}-\mathrm{NH}_{4}{ }^{+}$ dilution technique. Appl. environ. Microbiol. 37: 760-765

Blackburn, T H. (1993). Turnover of ${ }^{15} \mathrm{NH}_{4}{ }^{+}$tracer in sedi- ments. In: Kemp, P., Sherr, B. F., Sherr, E. B., Cole, J. J. (eds.) Current methods in aquatic microbial ecology. Lewis Publishers, New York, p. 643-648

Blackburn, T. H. Henriksen, K. (1983). Nitrogen cycling in different types of sediments from Danish waters. Limnol. Oceanogr. 28: $477-493$

Blackburn, T H., Christensen, D., Fenger, A. M., Henriksen, K., Iizumi, H., Iversen, N., Limpsaichol, P. (1987). Mineralization processes in mangrove and seagrass sediments. In: Hylleberg, J. (ed.) Ao Yon - a mangrove in the Andaman Sea. Institute of Ecology and Genetics, University of Aarhus, Aarhus, p. 22-32

Boto, K. G., Alongi, D. M., Nott, A. L. J. (1989). Dissolved organic carbon-bacterial interactions at sediment-water interface in a tropical mangrove system. Mar. Ecol. Prog. Ser. 51: 243-251

Boto, K. G., Bunt, J. S. (1981). Tidal export of particulate organic matter from a northern Australian mangrove system. Estuar. coast. Shelf Sci. 13: 247-255

Boto, K. G., Bunt, J. S. (1982). Carbon export from mangroves. In: Galbally, I. E., Freney, J. R. (eds.) The cycling of carbon, nitrogen, sulfur and phosphorus in terrestrial and aquatic systems. Australian Academy of Science, Canberra, p. 105-110

Boto, K. G., Wellington, J. T. (1988). Seasonal variations in concentrations and fluxes of dissolved organic and inorganic materials in a tropical, tidally dominated, mangrove waterway. Mar. Ecol. Prog. Ser. 50: 151-160

Carlson, P. R., Yarboro, L. A. (1988). Physical and biological control of mangrove pore water chemistry. In: Hook, D. D. (ed.) The ecology and management of wetlands. Timber Press, Portland, OR, p. 112-132

Carpenter, J. H., Seliger, H. H. (1968). Studies at Oyster Bay in Jamaica. West Indies. II. Effects of flow patterns and exchange on bioluminescent distributions. J. mar. Res. 26 : $256-271$

Dye, A. H., Lasiak, T. A. (1986). Microbenthos, meiobenthos and fiddler crabs: trophic interactions in a tropical mangrove sediment. Mar. Ecol. Prog. Ser. 32: 259-264

Hines, M. E., Lyons, W. B. (1982). Biogeochemistry of nearshore Bermudan sediments. I. Sulfate reduction rates and nutrient regeneration. Mar. Ecol. Prog. Ser. 8: 87-94

Holguin, G., Guzman, M. A., Bashan, Y. (1992). Two new nitrogen-fixing bacteria from the rhizosphere of mangrove trees: their isolation, identification and in vitro interaction with rhizosphere Staphylococcus sp. FEMS Microbiol. Ecol. 101: 207-216

Howarth, R. W., Teal, J. M. (1979). Sulfate reduction in a New England saltmarsh. Limnol. Oceanogr. 24: 999-1013

Jorgensen, B. B. (1980). Mineralization and bacterial cycling of carbon, nitrogen and sulphur in marine sediments. In: Ellwood, D. C., Hedger, J. N., Latham, M. J., Lynch, J. M., Slater, J. H. (eds.) Contemporary microbial ecology. Academic Press, London, p. 239-252

Kristensen, E., Blackburn, T. H. (1987). The fate of organic carbon and nitrogen in experimental marine sediment systems: influence of bioturbation and anoxia. J. mar. Res. 45: $231-257$

Kristensen, E., Andersen, F. Ø., Kofoed, L. H. (1988). Preliminary assessment of benthic community metabolism in a south-east Asian mangrove swamp. Mar. Ecol. Prog. Ser 48: $137-145$

Kristensen, E., Holmer, M., Bussarawit, N. (1991). Benthic metabolism and sulfate reduction in a southeastern Asian mangrove swamp. Mar. Ecol. Prog. Ser. 73: 93-103

Lovley, D. R. (1991). Dissimilatory Fe(III) and Mn(IV) reduction. Microbiol. Rev. 55: 259-287 
Mackin, J. E., Swider, K. T. (1989). Organic matter decomposition pathways and oxygen consumption in coastal marine sediments. J. mar. Res. 47: 681-716

Nedwell, D. B. (1975). Inorganic nitrogen metabolism in a eutrophicated tropical mangrove estuary. Water Res. 9: $221-231$

Nickerson, N. H., Thibodeau, F. R. (1985). Association between porewater sulfide concentrations and the distribution of mangroves. Biogeochemistry 1: 183-192

Nixon, S. W. (1980). Between coastal marshes and coastal water: a review of twenty years of speculation and research in the role of saltmarshes in estuarine productivity and water chemistry, In: Hamilton, P., Macdonald, K. B. (eds.) Estuarine and wetland processes with emphasis on modelling. Plenum Press, New York, p. 437-525

Odum, W. E., Heald, E. J. (1975). The detritus-based food web of an estuarine mangrove community. In: Cronin, L. E. (ed.) Estuarine research. Academic Press, New York, p. 265-286

Odum, W. E., Mclvor, C. C., Smith, T. J. (1982). The ecology of the mangroves of south Florida: a community profile. U.S. Fish and Wildlife Service, Office of Biological Services, Washington, DC, FWS/OBS-81/24

Rice, D. L., Tenore, K. R. (1981). Dynamics of carbon and nitrogen during the decomposition of detritus derived from estuarine macrophytes. Estuar. coast. Shelf Sci. 13: 681-690

Robertson, A. I. (1986). Leaf-burying crabs: their influence on energy flow and export from mixed mangrove forests (Rhizophora spp.) in northeastern Australia. J. exp. mar. Biol. Ecol. 102: 237-248

Robertson, A. I., Duke, N. C. (1987). Mangroves as nursery sites: comparisons of the abundance and species composition of fish and crustaceans in mangroves and other nearshore habitats in tropical Australia. Mar. Biol. 96: 193-205

Roden, E. E., Tuttle, J. H. (1993). Inorganic sulfur turnover in oligohaline estuarine sediments. Biogeochemistry 22: $81-105$

This article was submitted to the editor
Scholander, P. F, van Dam, L., Scholander, S. I. (1955). Gas exchange in the roots of mangroves. Am. J. Bot. 42: $92-98$

Seliger, H. H., McElroy, W. D. (1968). Studies at Oyster Bay in Jamaica, West Indies. I. Intensity patterns of bioluminescence in a natural environment. J. mar Res. 26: 244-255

Seliger, H. H., Fastie, W. G. (1968). Studies at Oyster Bay in Jamaica, West Indies. III. Measurements of underwater sunlight spectra. J. mar. Res. 26: 273-280

Skyring, G. W. (1985). Anaerobic microbial processes in coral reef sediments. Proc. 5th int. coral Reef Congr. 3: 421-425

Skyring, G. W., Oshrain, R. L., Wiebe, W. J. (1979). Sulfate reduction rates in Georgia marshland soils. Geomicrobiol. J. 1: $389-400$

Solórzano, L. (1969). Determination of ammonium in natural waters by the phenolhypochlorite method Limnol. Oceanogr. 14: 799-801

Sorokin, Yu. I. (1962). Experimental investigation of bacterial sulfate reduction in the Black Sea. Microbiology 32: $320-335$

Talling, J. F. (1973). The application of some electrochemical methods to the measurement of photosynthesis and respiration in fresh waters. Freshwat. Biol. 3: 335-362

Taylor, W. R., Seliger, H. H., Fastie, W. G., McElroy, W. D. (1966). Biological and physical observations on a phosphorescent bay in Falmouth Harbour, Jamaica, W.I. J. mar. Res. $24: 28-43$

Twilley, R. R. (1985). The exchange of organic carbon in basin mangrove forests on a southwest Florida estuary. Estuar. coast. Shelf Sci. 20:543-557

Yoshinari, T., Hynes, R., Knowles, R. (1977). Acetylene inhibition of nitrous oxide reduction and measurement of denitrification and nitrogen fixation in soils. Soil Biol. Biochem. 9: $177-183$

Zuberer, D., Silver, W. S. (1978). Biological dinitrogen fixation associated with Florida mangroves. Appl. environ. Microbiol. 35: $567-575$

Manuscript first received: June 4, 1993

Revised version accepted: April 12,1994 